\title{
Effects of feeding different amounts of supplemental glycerol on ruminal environment and digestibility of lactating dairy cows
}

\author{
J. Boyd, ${ }^{1,2}$ J. K. Bernard, and J. W. West \\ Department of Animal and Dairy Science, The University of Georgia, Tifton 31793
}

\begin{abstract}
A replicated $3 \times 3$ Latin square study was conducted to evaluate the effects of replacing a portion of ground corn in the diet with dietary glycerol on rumen environment, blood metabolites, and nutrient digestibility. Six rumen-cannulated Holstein cows, averaging $56 \pm$ 18 DIM and $38.0 \pm 8.2 \mathrm{~kg}$ of milk/d, were used in the study. Experimental periods included 3 wk for treatment adjustment period followed by 1 wk for data collection. Diets were corn silage based and balanced to be isocaloric and isonitrogenous. Treatments were $0 \mathrm{~g}$ of glycerol/d (control, CON), $200 \mathrm{~g}$ of glycerol/d (G2), and $400 \mathrm{~g}$ of glycerol/d (G4). Dry matter intake (DMI) decreased as the amount of glycerol fed increased. Milk yield was higher for CON and G2 cows in comparison with G4 cows. Milk fat percentage and yield were reduced when glycerol was fed compared with CON cows but increased the milk protein percentage at the highest concentration of dietary glycerol. These changes resulted in decreased energy-corrected milk yield and efficiency (milk/DMI) in diets supplemented with G4 compared with CON. No differences were observed in ruminal $\mathrm{pH}$ and ammonia concentrations. Molar proportions of acetate, valerate, and acetate:propionate ratio decreased, whereas propionate increased as the amount glycerol fed increased. Molar proportions of butyrate were greatest when glycerol was included in the diet compared with CON. Nutrient intake and digestion were not different among treatments. Results of this trial suggest that feeding increasing amounts of glycerol may decrease DMI and alters ruminal fermentation, resulting in reduced yield of milk, fat, and energy-corrected milk.
\end{abstract}

Key words: dietary glycerol, volatile fatty acid, efficiency

Received May 22, 2012.

Accepted October 2, 2012.

${ }^{1}$ Current address: US Dairy Forage Research Center, 1925 Linden Drive, West Madison, WI 53706.

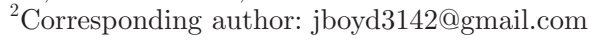

\section{INTRODUCTION}

The growth of the ethanol industry has increased the need for alternatives to corn in lactating cow diets. Biodiesel production has increased in the United Sates from 690 million gallons in 2009 to 802 million gallons in 2011 (Biofuels Digest, 2011). Industry growth is expected to increase availability and promote favorable pricing of glycerol, which is a byproduct of base-catalyzed transesterification of oil in the formation of methyl and ethyl FA esters in the production of biodiesel (Thompson and He, 2006) and the main byproduct of ethanol fermentation processing (Michnick et al., 1997). Purified glycerol is used in the food, pharmaceutical, and cosmetic industries, but the cost of refining crude glycerol to a high purity is cost prohibitive for many small refining operations (Pachauri and He, 2006). This leads to potentially a large source of crude glycerol available to livestock producers. According to the Food and Drug Administration (FDA, 2006), glycerol is recognized as a safe feed ingredient in animal diets. Glycerol is an odorless, colorless, hygroscopic, sweet-tasting liquid that has the potential to replace corn in the diet and has been predicted to have a feed value of 100 to $120 \%$ of corn, making it a viable alternative to corn (Hippen et al., 2008). Linke et al. (2004) calculated the $\mathrm{NE}_{\mathrm{L}}$ value of glycerol to be approximately $1.05 \mathrm{Mcal} / \mathrm{kg}$, which is $20 \%$ greater than corn. Schröder and Südekum (1999) calculated the energy density of glycerol to range between 0.90 to $1.03 \mathrm{Mcal}$ of $\mathrm{NE}_{\mathrm{L}} / \mathrm{kg}$. Also, several studies have reported that glycerol enhances rumen fermentation and improves feed efficiency (Garton et al., 1961; Dirksen et al., 1985; Hippen et al., 2008). Dietary glycerol seems to be extensively fermented to propionate by ruminal bacteria (Czerkawski and Breckenridge, 1972; Remond et al., 1993; Bergner et al., 1995), although level of feeding and method of delivery may affect the amount of glycerol that escapes fermentation (Kijora et al., 1998; DeFrain et al., 2004).

The increased availability may create an opportunity to use glycerol as an energy source in dairy rations and has led to a corresponding decline in price projections (Yazdani and Gonzalez, 2007). These changes 
may favor the use of glycerol in rations fed to livestock, especially with the rising corn costs and more crops being diverted to biofuel production.

Previously, glycerol has been a cost-prohibitive addition to the diet because of its value in other fields, but with growing biodiesel production and corn costs, the addition of glycerol to the ration is a possible choice for many producers. The objective of this study was to determine the effects of feeding diets with different levels of glycerol on rumen function, blood metabolites, and nutrient digestibility in lactating Holstein cows.

\section{MATERIALS AND METHODS}

The study was conducted May to July of 2008 at the University of Georgia, Tifton Campus Dairy Research Center. The protocol for the trial was approved by the University of Georgia Institutional Animal Care and Use Committee.

\section{Cows and Management}

Six early-lactation rumen-cannulated Holstein cows (4 multiparous and 2 primiparous) were used in the replicated $3 \times 3$ Latin square design study. Cows averaged $56 \pm 18$ DIM, $38.0 \pm 8.2 \mathrm{~kg} / \mathrm{d}$ of milk, $3.77 \pm$
$0.97 \%$ milk fat, and $2.72 \pm 0.2 \%$ milk protein at the beginning of the study. Cows were housed in a freestall barn with access to individual freestalls, free access to water, and fed behind Calan doors (American Calan Inc., Northwood, NH). Training for Calan doors was initiated in early April, and the study began in early May and continued until the end of July. Cows were cooled using fans and high-pressure misters. All diets contained $15 \mathrm{~g} / 907 \mathrm{~kg}$ of DM of Rumensin (Elanco Animal Health, Greenfield, IN).

Feed was mixed and delivered once daily. The amount of feed offered was adjusted each day to achieve 7 to $10 \%$ refusals. Diets were balanced to be isocaloric and isonitrogenous (Table 1). Cows were milked twice daily at 0400 and $1500 \mathrm{~h}$ during the study.

Cows were ranked by average daily milk yield, stage of lactation, and ECM during the standardization period, blocked into pairs by rank, and each pair was assigned randomly to 1 of the 3 experimental diets within block and progressed through the three 4-wk periods until exposed to all treatments.

\section{Experimental Treatments and Design}

The experimental design for this study was a replicated $3 \times 3$ Latin square. Each period consisted of 3

Table 1. Ingredient and chemical composition of experimental diets containing supplemental glycerol ${ }^{1}$

\begin{tabular}{|c|c|c|c|}
\hline \multirow[b]{2}{*}{ Item } & \multicolumn{3}{|c|}{ Diet $^{2}$} \\
\hline & $\mathrm{CON}$ & G2 & G4 \\
\hline \multicolumn{4}{|l|}{ Ingredient, $\%$ of DM } \\
\hline Corn silage & 38.5 & 38.5 & 38.5 \\
\hline Alfalfa hay & 10.6 & 10.6 & 10.6 \\
\hline Whole cottonseed & 1.82 & 1.82 & 1.82 \\
\hline Ground corn & 23.9 & 22.9 & 22.1 \\
\hline Wet brewers grain & 12.1 & 12.1 & 12.1 \\
\hline Concentrate $\operatorname{mix}^{3}$ & 13.2 & 13.2 & 13.2 \\
\hline Glycerol & 0 & 0.78 & 1.57 \\
\hline $\mathrm{DM},{ }^{4} \%$ & $50.0 \pm 0.5$ & $49.3 \pm 0.8$ & $49.2 \pm 0.6$ \\
\hline \multicolumn{4}{|l|}{ Chemical composition, ${ }^{4} \%$ of DM } \\
\hline NDF & $39.6 \pm 1.8$ & $40.9 \pm 1.9$ & $39.7 \pm 1.5$ \\
\hline $\mathrm{ADF}$ & $26.1 \pm 1.1$ & $27.1 \pm 1.6$ & $26.3 \pm 1.1$ \\
\hline $\mathrm{CP}$ & $17.2 \pm 0.5$ & $16.6 \pm 0.3$ & $16.7 \pm 0.6$ \\
\hline RUP $^{5}$ & 7.14 & 6.86 & 6.89 \\
\hline $\mathrm{RDP}^{5}$ & 10.05 & 9.74 & 9.81 \\
\hline Ether extract & $4.4 \pm 0.3$ & $4.7 \pm 0.3$ & $4.7 \pm 0.6$ \\
\hline \multicolumn{4}{|c|}{$\begin{array}{l}{ }^{2} \mathrm{CON}=\text { control: no glycerol added; } \mathrm{G} 2=\text { control }+200 \mathrm{~g} \text { of supplemental glycerol/d; G4 = control }+400 \mathrm{~g} \\
\text { of supplemental glycerol/d. }\end{array}$} \\
\hline \multicolumn{4}{|c|}{$\begin{array}{l}{ }^{3} \text { Composition of concentrate mix ( } \% \text { of DM): } 2.04 \% \text { Pro-Lak (H. J. Baker and Brother Inc., Westport, CT), } \\
6.06 \% \text { soybean meal } 48,0.151 \% \mathrm{Ca} 17 \%: \mathrm{P} 21 \%, 0.182 \% \text { potassium magnesium sulfate, } 0.454 \% \text { potassium bi- } \\
\text { carbonate, } 0.151 \% \text { limestone, } 0.151 \% \text { urea } 45 \% \mathrm{~N}, 0.027 \% \text { Availa- } 4 \text { (Zinpro Corp., Eden Prairie, MN), } 0.154 \% \\
\mathrm{MgO}, 0.227 \% \text { salt; } 0.530 \% \mathrm{Na} \text { bicarbonate, } 0.188 \% \text { yeast, } 0.121 \% \text { trace mineral premix }(2.91 \% \mathrm{Ca} ; 0.38 \% \\
\mathrm{Mg} ; 1.76 \% \mathrm{~S} ; 144 \mathrm{mg} / \mathrm{kg} \text { of } \mathrm{Co} ; 9,523 \mathrm{mg} / \mathrm{kg} \text { of Cu; } 1,465 \mathrm{mg} / \mathrm{kg} \text { of Fe; } 842 \mathrm{mg} / \mathrm{kg} \text { of I; } 28,617 \mathrm{mg} / \mathrm{kg} \text { of Mn; } \\
220 \mathrm{mg} / \mathrm{kg} \text { of Se; } 25,343 \mathrm{mg} / \mathrm{kg} \mathrm{Zn}), 0.01 \% \text { vitamin premix }(4,210,830 \mathrm{IU} / \mathrm{kg} \text { of vitamin A; } 1,684,330 \mathrm{IU} / \mathrm{kg} \\
\text { of vitamin D; } 21,045 \mathrm{IU} / \mathrm{kg} \text { of vitamin E), and } 0.229 \% \text { Rumensin } 3 \text { (Elanco Animal Health, Greenfield, IN). } \\
{ }^{4} \text { Results are presented as means } \pm \mathrm{SD} \text {. }\end{array}$} \\
\hline
\end{tabular}


wk for treatment adjustment followed by 1 wk for data collection. Dietary treatments consisted of a control without supplemental glycerol (CON), control plus $200 \mathrm{~g}$ of supplemental glycerol/d (G2), and control plus $400 \mathrm{~g}$ of supplemental glycerol/d (G4; Table 1). Glycerol was mixed into the TMR using a top-loading Super Data Ranger (American Calan Inc.) with whole cottonseed as a carrier. The glycerol was added to the whole cottonseed and mixed and the coated cottonseed was then added to the TMR in place of ground corn. Glycerol contained 80 to $85 \%$ glycerol with no more than $14 \%$ moisture, $7 \%$ sodium chloride, and methanol content of $18 \mathrm{ppm}$ (analysis provided by ADM Nutrition Alliance Inc., Quincy, IL).

\section{Data Collection}

The amount of feed offered and refused was recorded daily during the 7-d collection week. Milk yield was recorded at each milking $(2 \times)$ using electronic meters (Alpro; DeLaval, Kansas City, MO) and summed daily during the collection weeks. Milk samples were collected from 4 consecutive milkings each collection period and analyzed for concentrations of fat, protein, and SCC (Southeast Milk Inc., Belleview, FL). Energy-corrected milk yield was calculated as $\mathrm{ECM}=(0.327 \times \mathrm{kg}$ of milk $)+(12.95 \times \mathrm{kg}$ of fat $)+(7.65 \times \mathrm{kg}$ of protein $)$ (Tyrrell and Reid, 1965).

Blood samples from the coccygeal vessel were collected once during the each collection week for analysis of serum glucose and urea $\mathrm{N}$ using a Boehringer Mannheim/Hitachi 912 automated chemistry analyzer (Roche Laboratory Systems, Indianapolis, IN). Rumen samples were collected on $\mathrm{d} 3$ of each collection week at $0,2,4,6,8$, and $10 \mathrm{~h}$ after feeding. Approximately 50 $\mathrm{mL}$ of ruminal fluid was collected and strained through 3 layers of cheesecloth and immediately analyzed for $\mathrm{pH}$ and ammonia levels. A $10-\mathrm{mL}$ subsample was immediately mixed with $2 \mathrm{~mL}$ of metaphosphoric acid $(25 \% \mathrm{wt} / \mathrm{vol})$, centrifuged at $10,000 \times g$ for $10 \mathrm{~min}$, and the supernatant was collected and frozen for later analyses of VFA (Erwin et al., 1961) using a Thermo Scientific Trace GC Ultra (Thermo Fisher Scientific Inc., Bellefonte, PA).

Samples of TMR, refusals, and ingredients were collected 4 times during the collection week. The DM content was determined by drying in a forced-air oven at $55^{\circ} \mathrm{C}$ for $48 \mathrm{~h}$. Samples were composited by period and ground to pass through a 1-mm screen using a Wiley mill (Thomas Scientific, Swedesboro, NJ) for analysis of DM, CP, ether extract (AOAC, 1990), NDF (Van Soest et al., 1991), and ADF (AOAC, 1990).

\section{Digestibility Study}

Cows were fed $23 \mathrm{~g} / \mathrm{d}$ (DM basis) of $\mathrm{Cr}_{2} \mathrm{O}_{3}$ mixed into the experimental diet beginning $10 \mathrm{~d}$ before the 4-d collection period each collection week. Powdered $\mathrm{Cr}_{2} \mathrm{O}_{3}$ was mixed with ground corn as a carrier at a rate of $3.82 \mathrm{~g}$ of corn $/ \mathrm{kg}$ of DM in an upright mixer. The $\mathrm{Cr}_{2} \mathrm{O}_{3}$ corn blend was added to the diet and mixed daily. Daily feed and ort samples were collected during the 4-d collection period. Fecal grab samples were collected during the collection period at 12 -h intervals, with the collection time advancing by $3 \mathrm{~h}$ each day to represent 0300, 0600, 0900, 1200, 1500, 1800, 2100, and $2400 \mathrm{~h}$. Fecal samples were frozen at $-5^{\circ} \mathrm{C}$ until composited by cow. Samples of feed, orts, and feces were compiled by cow and dried at $55^{\circ} \mathrm{C}$ and ground to pass through a 1-mm screen using a Wiley mill and stored for analysis of $\mathrm{CP}, \mathrm{NDF}$, and ADF as described previously. Chromium content of feed, orts, and feces was determined using atomic absorption spectrophotometry (AAnalyst 100/300; Perkin Elmer, Bellefontaine, PA) following wet ashing (Ferret et al., 1999).

\section{Statistical Analysis}

Data were analyzed as a $3 \times 3$ Latin square design using PROC MIXED of SAS version 9.1 (SAS Institute, 2004). Significance was defined as $P<0.05$ and trends as $0.05 \leq P \leq 0.15$. Values are reported are least squares means and associated standard errors. Model 1 was used for analysis of intake, production, blood, and apparent digestibility. Model 2 was used for analysis of VFA, pH, and ammonia and included effects of time, period, and treatment. Interactions tested were hour by treatment for ruminal data. Sample time was included as a repeated measure for model 2 . When significance was determined, pairwise $t$-tests with a Tukey adjustment were performed between treatment means using the PDIFF statement in SAS. The models were as follows:

$$
\begin{gathered}
Y_{i j m k}=\mu+\beta_{i}+P_{j}+C_{k}+\varepsilon_{i j m k} ; \\
Y_{i j l n}=\mu+\beta_{i}+P_{j}+C_{k}+H_{l}+\beta H_{i l}+\varepsilon_{i j k l n},
\end{gathered}
$$

where $Y_{i j m k}$ and $Y_{i j l n}=$ variable responses, $\mu=$ general mean, $\beta_{i}=$ fixed effect of treatment $(i=1, \ldots, 3), P_{j}$ = fixed effect of period $(j=1, \ldots, 3), C_{k}=$ fixed effect of cow $(k=1, \ldots, 6), H_{l}=$ fixed effect of hour $(l=0$, $\ldots, 10), \beta H_{i l}=$ interaction of treatment and hour, and $\varepsilon_{i j m k}$ and $\varepsilon_{i j k l n}=$ residual errors. 
Table 2. Performance and blood metabolites of lactating Holstein cows fed diets supplemented with different amounts of supplemental glycerol ( $\mathrm{n}=72$ milk samples; $\mathrm{n}=18$ serum samples)

\begin{tabular}{|c|c|c|c|c|c|}
\hline \multirow[b]{2}{*}{ Item } & \multicolumn{3}{|c|}{ Diet $^{1}$} & \multirow[b]{2}{*}{$\mathrm{SE}$} & \multirow[b]{2}{*}{$P$-value } \\
\hline & $\mathrm{CON}$ & G2 & G4 & & \\
\hline Milk, $\mathrm{kg} / \mathrm{d}$ & $37.9^{\mathrm{a}}$ & $37.3^{\mathrm{a}}$ & $35.5^{\mathrm{b}}$ & 0.52 & 0.004 \\
\hline Fat, $\%$ & $3.46^{\mathrm{a}}$ & $3.31^{\mathrm{b}}$ & $3.35^{\mathrm{b}}$ & 0.03 & 0.004 \\
\hline Fat, kg/d & $1.33^{\mathrm{a}}$ & $1.24^{\mathrm{b}}$ & $1.19^{\mathrm{b}}$ & 0.03 & 0.0009 \\
\hline Protein, $\%$ & $2.76^{\mathrm{a}}$ & $2.75^{\mathrm{a}}$ & $2.81^{\mathrm{b}}$ & 0.005 & 0.0001 \\
\hline Protein, $\mathrm{kg} / \mathrm{d}$ & 1.04 & 1.02 & 1.00 & 0.02 & 0.06 \\
\hline ECM, kg/d & $37.6^{\mathrm{a}}$ & $36.1^{\mathrm{ab}}$ & $34.6^{\mathrm{b}}$ & 0.61 & 0.003 \\
\hline \multicolumn{6}{|l|}{ Efficiency } \\
\hline ECM/DMI & 1.54 & 1.55 & 1.48 & 0.02 & 0.10 \\
\hline Milk/DMI & $1.55^{\mathrm{ac}}$ & $1.60^{\mathrm{ab}}$ & $1.51^{\mathrm{c}}$ & 0.03 & 0.05 \\
\hline \multicolumn{6}{|l|}{ Serum metabolite } \\
\hline Glucose, mg/dL & 62.7 & 62.5 & 63.3 & 1.3 & 0.89 \\
\hline Urea N, mg/dL & 21.7 & 21.8 & 20.5 & 0.4 & 0.09 \\
\hline
\end{tabular}

${ }^{\mathrm{a}-\mathrm{c}}$ Means within a row with unlike superscripts differ $(P<0.05)$.

${ }^{1} \mathrm{CON}=$ control: no glycerol added; G2 $=$ control $+200 \mathrm{~g}$ of supplemental glycerol $/ \mathrm{d} ; \mathrm{G} 4=$ control $+400 \mathrm{~g}$ of supplemental glycerol/d.

\section{RESULTS AND DISCUSSION}

The chemical composition of the experimental diets is reported in Table 1. Nutrient concentrations were similar for all diets except that concentrations of ether extract were slightly higher when glycerol was included in the diet.

Milk yield was reduced $(P=0.004)$ by 1.8 and 2.4 $\mathrm{kg} / \mathrm{d}$ for G4 compared with CON and G2. Inclusion of glycerol in the diet resulted in a reduction in milk fat percentage $(P=0.004)$ and yield $(P=0.0009)$ compared with CON. In contrast, milk protein percentage increased $(P=0.0001)$ at the higher level of glycerol supplementation compared with CON and G2. These results are in contrast to earlier work reported by Donkin and Doane (2007) in which no differences were observed in milk yield or composition when glycerol replaced corn in the diet. Chung et al. (2007) included dried glycerol (food grade, $65 \%$ glycerol) in the diet of transition cows and also reported no effect on milk yield or composition. Linke et al. (2004) fed glycerol at the rate of 498 or $998 \mathrm{~g} / \mathrm{d}$ in the diet of mid-lactation Holstein and Brown Swiss cows in a $3 \times 3$ Latin square, with no effect on DMI, milk yield, or FCM, but observed an improvement in feed efficiency with the inclusion of glycerol with milk to feed ratios of 1.46, 1.59, and 1.60 for the control, 498 and $998 \mathrm{~g} / \mathrm{d}$, respectively. Feed efficiency (milk/DMI) was reduced $(P=$ 0.05) for G4 compared with G2 and CON. Also, ECM was reduced $(P=0.003)$ for $\mathrm{G} 4$ compared with $\mathrm{CON}$ and a tendency $(P=0.10)$ for lower efficiency (ECM/ DMI) was found in the current study. These results are in agreement with DeFrain et al. (2004) who reported reduced ECM when glycerol was fed. No differences were observed among treatments in concentrations of serum glucose or urea $\mathrm{N}$, although a trend $(P=0.09)$ for reduced serum urea $\mathrm{N}$ was observed with increasing amounts of glycerol in the diet (Table 2).

No differences were observed for the interaction of treatment and sampling time; thus, only the main effects are reported. No differences were observed among treatments for ruminal $\mathrm{pH}$ (average 6.1), but a weak trend $(P=0.14)$ existed for decreased ruminal ammonia concentrations with the addition of glycerol to the diet. Ruminal ammonia concentrations were 12.1, 11.7, and 9.8 for CON, G2, and G4, respectively (Table 3). No differences were observed in total VFA concentration among treatments. Molar proportions of acetate, valerate, and acetate:propionate ratio decreased $(P=$ $0.0001)$, whereas molar proportions of propionate $(P$ $=0.0002)$ increased as the amount of glycerol fed increased. Molar proportions of butyrate were highest $(P$ $=0.0001)$ for diets supplemented with glycerol compared with CON. No differences were observed in molar proportions of isobutyrate or isovalerate.

The effects of supplemental glycerol on ruminal VFA concentrations are in agreement with previous reports. Schröder and Südekum (1999) examined the effects of feeding glycerol on ruminal fermentation using ruminally cannulated steers and reported that although the addition of glycerol did not affect diet digestibility, it did decrease the acetate:propionate ratio, linearly increased ruminal butyrate concentrations, and stimulated increased water intake. Schröder and Südekum (1999) concluded that the inclusion of dietary glycerol would be beneficial to the dairy cow because it would increase ruminal propionate, increasing the supply of gluconeogenic substrate to the liver. Also, the increased 
Table 3. Ruminal $\mathrm{pH}$ and VFA concentrations of lactating Holstein cows fed diets supplemented with different amounts of supplemental glycerol $(\mathrm{n}=108 \text { rumen fluid samples })^{1}$

\begin{tabular}{|c|c|c|c|c|c|}
\hline \multirow[b]{2}{*}{ Item } & \multicolumn{3}{|c|}{$\operatorname{Diet}^{2}$} & \multirow[b]{2}{*}{$\mathrm{SE}$} & \multirow[b]{2}{*}{$P$-value } \\
\hline & $\mathrm{CON}$ & G2 & G4 & & \\
\hline $\mathrm{pH}$ & 6.1 & 6.0 & 6.1 & 0.04 & 0.64 \\
\hline Ammonia, \% & 12.1 & 11.7 & 9.8 & 0.86 & 0.14 \\
\hline Total VFA, mmol & 46.7 & 52.2 & 49.0 & 2.3 & 0.24 \\
\hline \multicolumn{6}{|l|}{ Composition, $\%$} \\
\hline Acetate & $61.1^{\mathrm{a}}$ & $59.1^{\mathrm{b}}$ & $57.6^{\mathrm{c}}$ & 0.39 & 0.0001 \\
\hline Propionate & $23.3^{\mathrm{a}}$ & $24.1^{\mathrm{b}}$ & $25.4^{\mathrm{c}}$ & 0.35 & 0.0002 \\
\hline Butyrate & $11.4^{\mathrm{a}}$ & $12.3^{\mathrm{b}}$ & $12.4^{\mathrm{b}}$ & 0.15 & 0.0001 \\
\hline Isobutyrate & 1.3 & 1.2 & 1.2 & 0.06 & 0.91 \\
\hline Isovalerate & 1.5 & 1.5 & 1.5 & 0.04 & 0.53 \\
\hline Valerate & $1.5^{\mathrm{a}}$ & $1.7^{\mathrm{b}}$ & $1.8^{\mathrm{b}}$ & 0.05 & 0.0001 \\
\hline Acetate:propionate & $2.7^{\mathrm{a}}$ & $2.5^{\mathrm{b}}$ & $2.3^{\mathrm{c}}$ & 0.05 & 0.0001 \\
\hline
\end{tabular}

ruminal butyrate would support the growth of ruminal epithelial tissue and possibly increase nutrient absorption from the rumen as proposed by Dirksen et al. (1985).

DeFrain et al. (2004) conducted a transition cow study with the inclusion of glycerol. Those researchers reported that rumen fluid collected postpartum from cows offered glycerol had a greater total VFA concentration, increased molar proportions of propionate, and decreased acetate:propionate ratio compared with the control. Butyrate concentrations also showed a tendency to increase linearly in cows fed glycerol treatment compared with CON.

Linke et al. (2004) reported an increase in molar proportions of propionate and butyrate with increasing glycerol without any difference in DMI, milk yield, or
FCM. They also reported molar proportions of acetate decreased when cows were provided supplemental glycerol through drenching or mixing in their diet. Molar proportions of propionate and butyrate increased with either route of administration with peak concentration observed $4 \mathrm{~h}$ after consumption. Concentrations of glycerol in blood plasma increased when cows were drenched or tubed but not when they were fed glycerol. Plasma insulin and BHBA concentrations increased when cows were drenched or tubed compared with those fed glycerol in their diets. These researchers concluded that for glycerol to be gluconeogenic it must be delivered in water to associate with the liquid fraction of the rumen contents or be able to bypass the rumen and be absorbed as glycerol and converted to glucose by the liver. Glycerol that is available to the rumen microbes

Table 4. Nutrient intake and apparent digestibility of lactating Holstein cows fed diets supplemented with different amounts of supplemental glycerol $(\mathrm{n}=108$ intake observations; $\mathrm{n}=144$ fecal samples)

\begin{tabular}{lccccc}
\hline & \multicolumn{5}{c}{ Diet $^{1}$} \\
Item & CON & G2 & G4 & SE & $P$-value \\
\hline Intake, kg/d & & & & \\
DM & $24.3^{\mathrm{a}}$ & $23.1^{\mathrm{b}}$ & $23.4^{\mathrm{b}}$ & 0.24 & 0.003 \\
CP & 3.5 & 3.1 & 3.1 & 0.1 & 0.21 \\
NDF & 7.8 & 7.4 & 7.5 & 0.4 & 0.70 \\
ADF & 5.2 & 4.9 & 4.8 & 0.3 & 0.60 \\
Apparent digestibility, $\%$ & & & & & \\
DM & 68.5 & 66.9 & 65.6 & 2.3 & 0.66 \\
CP & 71.8 & 69.1 & 68.2 & 1.8 & 0.36 \\
NDF & 47.5 & 46.3 & 48.6 & 3.5 & 0.90 \\
ADF & 44.9 & 43.6 & 40.9 & 4.1 & 0.78 \\
\hline
\end{tabular}

${ }_{\mathrm{a}, \mathrm{b}}$ Means within a row with unlike superscripts differ $(P<0.05)$.

${ }^{1} \mathrm{CON}=$ control: no glycerol added; G2 $=$ control $+200 \mathrm{~g}$ of supplemental glycerol $/ \mathrm{d} ; \mathrm{G} 4=$ control $+400 \mathrm{~g}$ of supplemental glycerol/d. 
is highly fermentable and is converted to propionic and butyric acids. Garton et al. (1961) conducted in vitro incubations of glycerol and observed that almost $25 \%$ of glycerol had disappeared after $2 \mathrm{~h}$ and almost $90 \%$ of the glycerol was undetectable after an 8-h incubation.

The DMI was reduced $(P=0.003)$ with the inclusion of glycerol for both G2 and G4 compared with CON (Table 4). This is in contrast to a previous trial (Boyd et al., 2011) in which no differences in DMI were observed when lactating cows were fed diets supplemented with up to $400 \mathrm{~g}$ of glycerol/d for $10 \mathrm{wk}$. Other researchers (DeFrain et al., 2004; Linke et al., 2004) have not observed any effect on DMI with the inclusion of glycerol in the diet. However, no differences in nutrient intake or apparent digestibility (Table 4) were observed among treatments. These results are in agreement with previous research reported by Schröder and Südekum (1999) and Donkin and Doane (2007) who reported no effects on nutrient digestibility with the inclusion of glycerol in the diet.

\section{CONCLUSIONS}

Inclusion of dietary glycerol in the ration of dairy cows affected milk yield and components, ECM, and ruminal fermentation patterns. The effects on ruminal fermentation are in agreement with several earlier studies. Addition of rumen-fermentable glycerol decreased molar proportions of acetate and acetate:propionate ratio and increased molar proportions of propionate and butyrate, which should increase the supply of gluconeogenic precursors and support the growth of ruminal epithelial tissue and potentially increase nutrient absorption from the rumen.

\section{ACKNOWLEDGMENTS}

The authors thank ADM Alliance Nutrition Inc. (Quincy, IL) for donating the glycerol for this study. Also, thanks to the staff at the Dairy Research Center on the University of Georgia (Tifton Campus) for their assistance with animal care and sample collection and to Melissa Tawzer and Melanie Renney (University of Georgia Animal and Dairy Science Department) for their laboratory and technical assistance.

\section{REFERENCES}

AOAC (Association of Official Analytical Chemists). 1990. Official Methods of Analysis. 15th ed. AOAC, Washington, DC.

Bergner, H., C. Kijora, Z. Ceresnakova, and J. Szakacs. 1995. In vitro studies on glycerol transformation by rumen microorganisms. Arch. Tierernahr. 48:245-256.
Biofuels Digest. 2011. 2011 US biodiesel production sets all-time record. Accessed July 2012. http://www.biofuelsdigest.com/ bdigest/2011/11/29/2011-us-biodiesel-production-sets-all-timerecord/.

Boyd, J., J. W. West, and J. K. Bernard. 2011. Effects of the addition of direct-fed microbials and glycerol to the diet of lactating dairy cows on milk yield and apparent efficiency of yield. J. Dairy Sci. 94:4616-4622.

Chung, Y.-H., D. E. Rico, C. M. Martinez, T. W. Cassidy, V. Noirot, A. Ames, and G. A. Varga. 2007. Effects of feeding dry glycerin to early postpartum Holstein cows on lactational performance and metabolic profiles. J. Dairy Sci. 90:5682-5691.

Czerkawski, J. W., and G. Breckenridge. 1972. Fermentation of various glycolytic intermediates and other compounds by rumen microorganisms, with particular reference to methane production. Br. J. Nutr. 27:131-146.

DeFrain, J. M., A. R. Hippen, K. F. Kalscheur, and P. W. Jardon. 2004. Feeding glycerol to transition dairy cows: Effects on blood metabolites and lactation performance. J. Dairy Sci. 87:41954206.

Dirksen, G. U., H. G. Liebich, and E. Mayer. 1985. Adaptive changes of the ruminal mucosa and their functional and clinical significance. Bovine Pract. 20:116-120.

Donkin, S., and P. Doane. 2007. Glycerol as a feed ingredient in dairy rations. Tri-State Nutrition Dairy Nutrition Conference. Accessed Feb. 10, 2009. http://tristatedairy.osu.edu/Proceedings\%202007/ Donkin\%20paper.pdf.

Erwin, E. S., G. J. Marco, and E. M. Emery. 1961. Volatile fatty acid analyses of blood and rumen fluid by gas chromatography. J. Dairy Sci. 44:1768-1771.

FDA (Food and Drug Administration). 2006. Code of Federal Regulations. Title 21-Food and Drugs. Vol. 6, 21CFR582.1320. Accessed Jul. 26, 2011. http://edocket.access.gpo.gov/cfr_2002/ aprqtr/21cfr582.1320.htm.

Ferret, A., J. Plaixats, G. Caja, J. Gasa, and P. Prio. 1999. Using markers to establish apparent dry matter digestibility, faecal output and dry matter intake in dairy ewes fed Italian ryegrass hay or alfalfa hay. Small Rumin. Res. 33:145-152.

Garton, G. A., A. K. Lough, and E. Vioque. 1961. Glyceride hydrolysis and glycerol fermentation by sheep rumen contents. J. Gen. Microbiol. 25:215-225.

Hippen, A. R., J. M. DeFrain, and P. L. Linke. 2008. Glycerol and other energy sources for metabolism and production of transition dairy cows. Pages 1-6 in Proc. 19th Annu. Florida Rumin. Nutr. Symp., Gainesville, FL. Department of Animal Science, University of Florida, Gainesville.

Kijora, C., H. Bergner, K.-P. Götz, J. Bartelt, J. Szakács, and A. Sommer. 1998. Research note: Investigation on the metabolism of glycerol in the rumen of bulls. Arch. Tierernahr. 51:341-348.

Linke, P. L., J. M. DeFrain, A. R. Hippen, and P. W. Jardon. 2004. Ruminal and plasma responses in dairy cows to drenching or feeding glycerol. J. Dairy Sci. 87(Suppl. 1):343. (Abstr.)

Michnick, S., J. L. Roustan, F. Remize, P. Barre, and S. Dequin. 1997. Modulation of glycerol and ethanol yields during alcoholic fermentation in Saccharomyces cerevisiae strains over expressed or disrupted for GPD1 encoding glycerol 3-phosphate dehydrogenase. Yeast 13:783-793.

Pachauri, N., and B. He. 2006. Value-added utilization of crude glycerol from biodiesel production: A survey of current research activities. Paper no. 066223 in Annual International Meeting, Portland, OR. ASABE, St. Joseph, MI. Accessed Nov. 10, 2008. https:// elibrary.asabe.org/techpapers.asp?confid=por2006.

Remond, B., E. Souday, and J. P. Jouany. 1993. In vitro and In vivo fermentation of glycerol by rumen microbes. Anim. Feed Sci. Technol. 41:121-132.

SAS Institute. 2004. User's Guide: Statistics. Version 9.1 ed. SAS Inst. Inc., Cary, NC.

Schröder, A., and K. Südekum. 1999. Glycerol as a by-product of biodiesel production in diets for ruminants. Proc. 10th Intl. Rapeseed 
Congr., Canberra, Australia. The Regional Institute Ltd., Gosford, Australia. Accessed Jun. 10, 2008. http://www.regional.org. $\mathrm{au} / \mathrm{au} / \mathrm{gcirc} / 1 / 241 . h t m \#$ TopOfPage.

Thompson, J. C., and B. B. He. 2006. Characterization of crude glycerol from biodiesel production from multiple feedstocks. Appl. Eng. Agric. 22:261-265.

Tyrrell, H. F., and J. T. Reid. 1965. Prediction of the energy value of cow's milk. J. Dairy Sci. 48:1215-1223.
Van Soest, P. J., J. B. Robertson, and B. A. Lewis. 1991. Methods for dietary fiber, neutral detergent fiber, nonstarch polysaccharides in relation to animal nutrition. J. Dairy Sci. 74:3583-3597.

Yazdani, S. S., and R. Gonzalez. 2007. Anaerobic fermentation of glycerol: A path to economic viability for the biofuels industry. Curr. Opin. Biotechnol. 18:213-219. 